\title{
Tracing the Materiality of Feathers in Stone Age North-Eastern Europe
}

\author{
Kristiina Mannermaa' (1) \& Tuija Kirkinen² (1)
}

The use of feathers in ritual costumes and everyday clothing is well described in ethnographic sources throughout the world. From the same sources we know that bird wings and feathers were loaded with meaning in traditional societies worldwide. However, direct archaeological evidence of prehistoric use of feathers is still extremely scarce. Hence, feathers belong to the 'missing majority': items that are absent from the archaeological record but which we can assume to have been of importance. Here we present microscopic analysis of soil samples from hunter-gatherer burial contexts which reveal the first direct evidence of the use of feathers in the Mesolithic period of north-eastern Europe.

Keywords: microarchaeology, wings, feathers, birds, burial practices, masks

\footnotetext{
${ }^{1}$ Department of Cultures, Archaeology, University of Helsinki and Institute of History and Archaeology, University of Tartu kristiina.mannermaa@helsinki.fi

${ }^{2}$ Department of Cultures, Archaeology, University of Helsinki tuija.kirkinen@helsinki.fi
}

This is an Open Access article distributed under the terms of the Creative Commons 4.0 International licence (CC BY 4.0) (http://creativecommons.org/licenses/by/4.0/), which permits unrestricted use, distribution, and reproduction in any medium, provided the original work is properly cited. 


\section{Introduction}

Use of feathers in both ritual costumes and paraphernalia and everyday clothing is well described in ethnographic and anthropological sources throughout the world (e.g. Holmberg 1922; Sillitoe 1988; Reina \& Kensington I99I; Siikala 2002:282; Aguilera 20I0; Kelly 20I0). The sources bear witness to the importance of bird feathers and skins as raw materials for garments such as clothes, headgear, pouches, bags and arrowheads. Given that the insulating qualities of feathers are an important aspect of their materiality, down has long been used as a stuffing material for pillows, quilts and clothes in colder regions (Hurcombe 20I 4:9I-92; Rast-Eicher 20I6:29I and cited references; Kirkinen et al. in press).

Worldwide, the most widespread use of feathers has been for decorative purposes (Serjeantson 2009:207). However, when people attached feathers to their garments, they did so for many purposes besides aesthetics. For example, early farmers in North America domesticated the turkey (Mealeagris gallopavo) for its feathers, which were used for colourful blankets and winter cloaks, while the most spectacular feathers were saved for ceremonial costumes (Gilligan 20I9:I72-I73).

Our understanding of the uses of feathers in Mesolithic and Neolithic burial practices has relied on indirect evidence of wing bones (Mannermaa 2006, 2008a, 20I8; Fribus \& Grushin 2017; Russel 20I8). In the absence of feathers themselves, the species, the bone elements and the butchery marks sometimes suggest the specific purposes for which feathers may have been used (Mannermaa 2006; Serjeantson 2009:199-203).

The first section of this paper presents ethnographic examples of the uses of feathers. The second section of this paper presents illustrative examples of osteological evidence for prehistoric use of bird wings and thus probably feathers. Our examples derive from Tamula in Estonia, Zvejnieki in Latvia, Vedbæk in Denmark, Chumysh-Perekat in Altai, western Siberia and Çatalhöyük in Turkey. The first four burial sites are hunter-gatherer populations, while Çatalhöyük represents an agricultural population.

However, the picture gained on the basis of osteological assemblages is unlikely to give a full idea of how commonly feathers were used in ornamentation or in the burial practices of prehistoric groups. Feathers belong to the 'missing majority': items absent from the archaeological record but which we can assume to have once been of importance (e.g. Hurcombe 20I 4:68). How can we then obtain more evidence of the use of feathers in prehistory? The third part of the paper explores the possibility that microscopic analysis of soil samples from archaeological contexts, in this case burials, may be able to reveal finds of feathers. 
Recent advances made in (micro)archaeology and microscopy have revealed fibres in, for example, soil samples (Beatty \& Bonnichsen I994; Morell 1994; Wilson 2008:I24; Ahola et al. 2018; Metcalfe 2018; Kirkinen 20I9) and Middle Pleistocene coprolite samples (Taru \& Backwell 20I3). Microscopic analysis of soil samples from prehistoric contexts may also provide evidence of the use of feathers in those cases when no wing bones can be associated with human activities. These findings would have the potential to completely change our present understanding of prehistoric peoples by demonstrating the importance of feathers, for example, in ceremonies, as ornaments and on parts of costumes.

We introduce the main methods used in microscopic archaeology and present some very preliminary results from the experimental first phase of our study of soil samples from archaeological sites in north-eastern Europe, with the aim of expanding evidence for the use of bird wings and feathers in archaeological mortuary contexts.

\section{Significance of feathers - ethnographic examples}

In traditional cultures around the world, feathers have been used in ceremonial clothes, on headgear and with masks (Figures I-6). In some cases, only

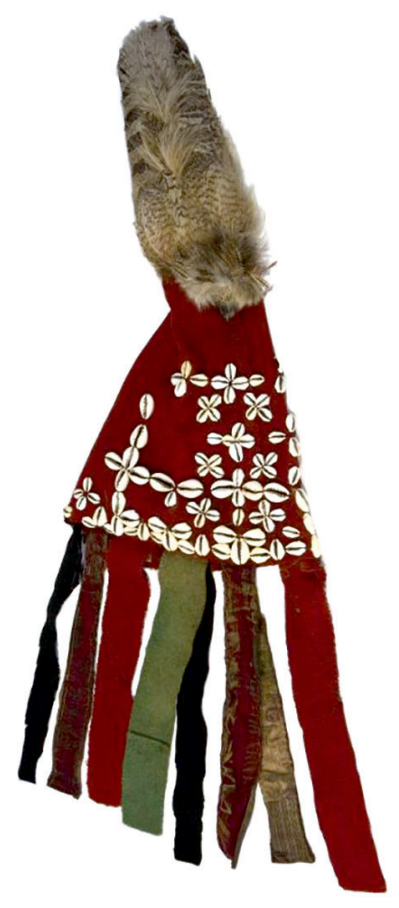

Figure I. Eurasian eagle-owl (Bubo bubo) feathers used in a shaman's headgear from the early 20 th century. Materials are wool, cowrie shells, eagle-owl feather, brocade and nibs. Photo: Kunstkamera MAЭ, St Petersburg, Russia (No. 506I-2). 


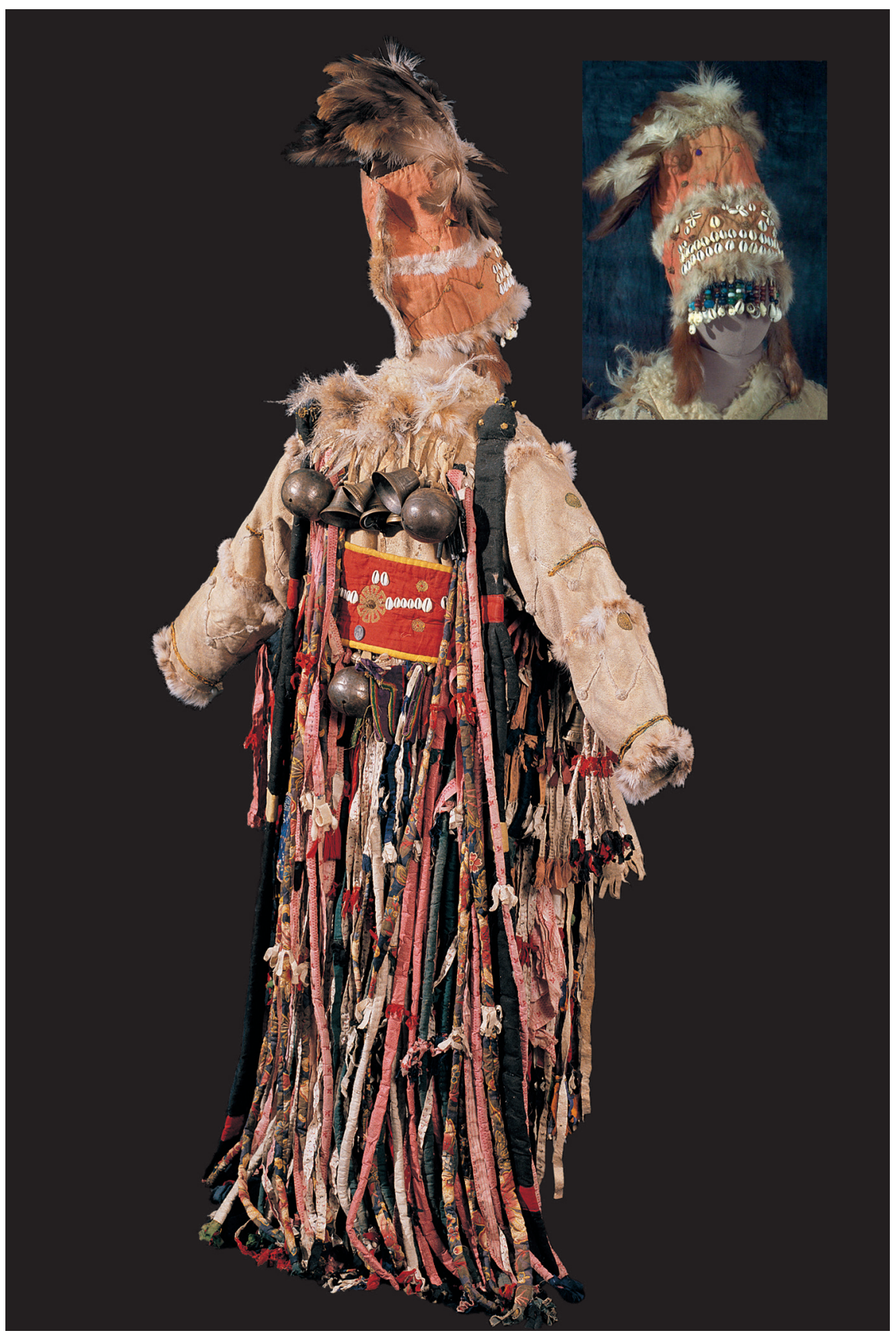

Figure 2. Shaman's dress and headgear containing feathers from the Black Kite (Milvus migrans). Birds of prey helped the shaman with her/his sacrifices to spirits and to enter into a trance (Sem \& Solovyeva 2006:268). Tomsk region, western Siberia. Photo: Russian Museum of Ethnography, St Petersburg, Russia (No. 579-4, 5). 


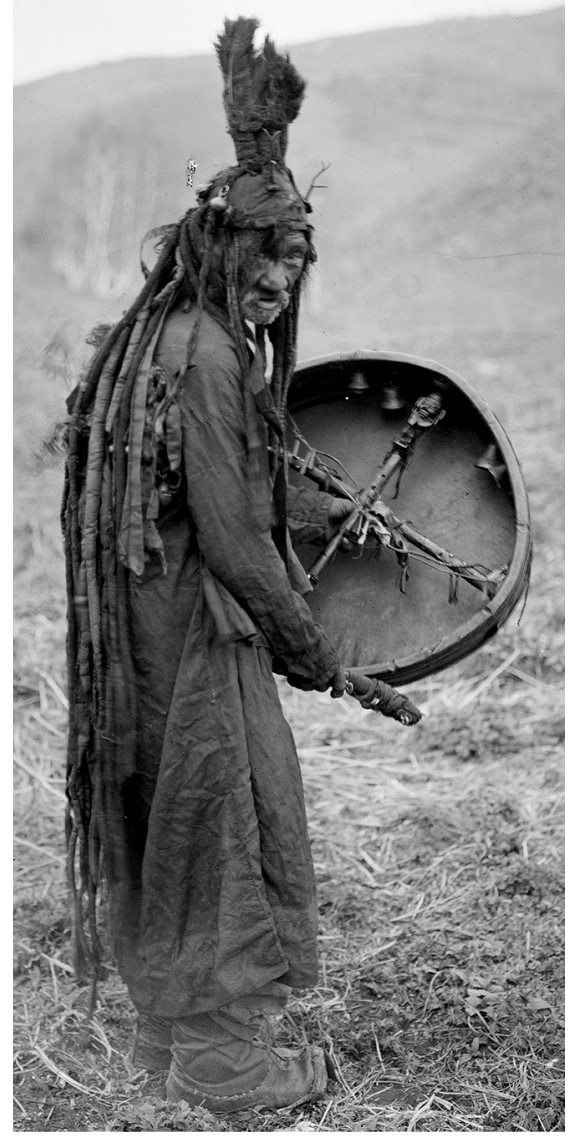

Figure 3. A male shaman, Otsir Böö, wears headgear with feathers from an eagle or owl. Bajangol, Mankhatai, Mongolia. Photo: Sakari Pälsi r909. Finnish Heritage Agency, Finland.

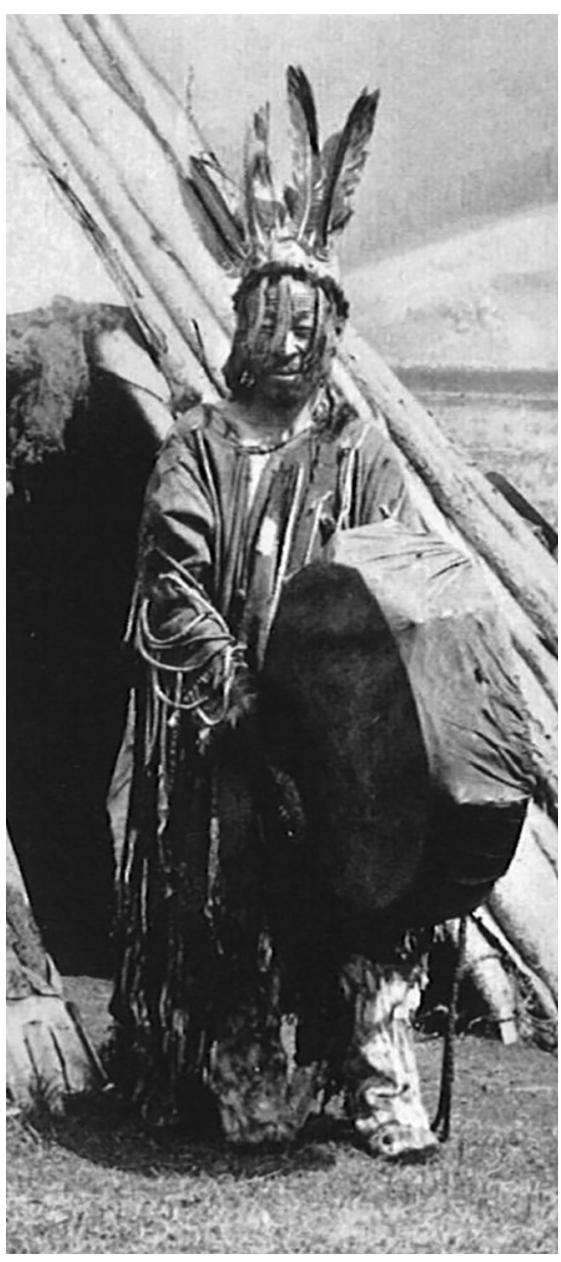

Figure 4. Mongolian shaman's headdress with eagle or Eurasian eagle-owl (Bubo bubo) feathers. Upper Yenisei River, I903. Photo: Russian Museum of Ethnography, St Petersburg, Russia (No. I I43-I46).

single feathers or bundles of feathers were used (Figures I-4), while sometimes whole wings or other parts of birds were attached to garments (Figures 5-6). Accorded manifold meanings, feathers facilitated the transformation from human to bird and from the land of the living to the land of the dead.

For example, for a Tuva shaman in southern Siberia between Russia and Mongolia, headgear decorated with feathers and plumes symbolised the shaman's ability to journey to the other world (Taksami 200I:I3). Moreover, wings of the Eurasian eagle-owl (Bubo bubo) were used as part of a shamanic costume in the Yenisei River region of the western Altai Moun- 


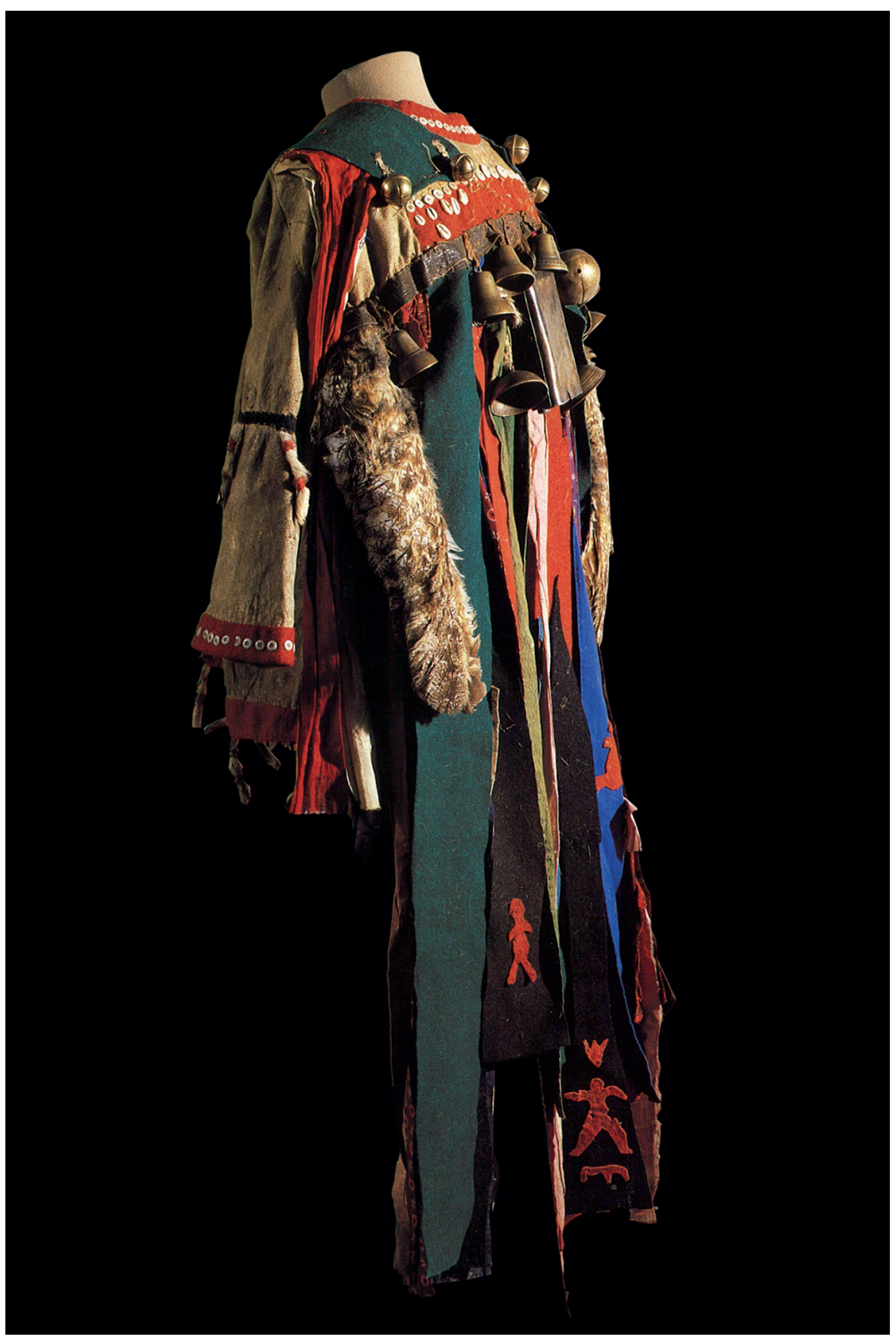

Figure 5. The wings, feet and head on the back of this shaman costume show that the Eurasian eagle-owl (Bubo bubo) was the shaman's main spirit helper. Eastern Siberia, Minusinsk Uezd. Photo: Russian Museum of Ethnography, St Petersburg, Russia (No. 600-I). 


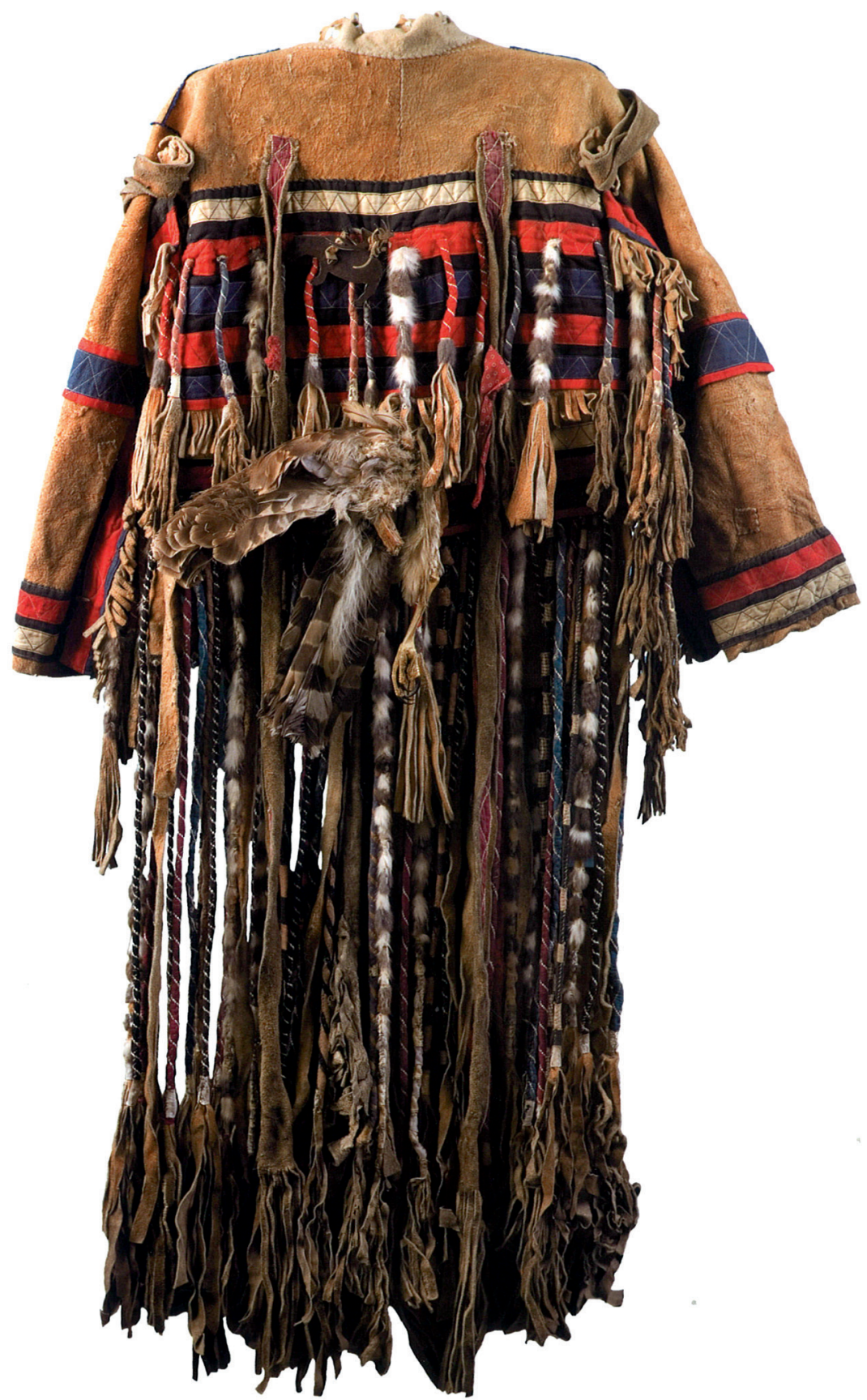

Figure 6. This shaman costume, from the Evenks people in Yakutsk Oblast, eastern Siberia, symbolises the cosmos. The shaman's main guardian spirit was the Eurasian eagle-owl (Bubo bubo) (wings and legs are sewn onto the back). Photo: Russian Museum of Ethnography, St Petersburg, Russia (No. 8762-19242). 
tains in northeast Russia. In such a context, the dress symbolised the bird, and its most important attributes were the wings attached on either the shoulders or breast (Lehtinen 2002a).

Not only in Siberia but also in many other parts of the world, the fringe of a shaman's dress imitated the bird feather coat and referred to the shaman's ability to transform him- or herself into a bird (Prokofyeva I963; Reina \& Kensington I99I; Lehtinen 2002b:II8, I2I, I27). For example, in Amazonia a feathered ceremonial dress represented part of a shaman's transformation into altered form (Furst 199I). Taksami (200I:80) emphasises that the experience of flying during a trance is reinforced by using birdlike attributes.

Ing-Marie Back Danielsson (2007:209, 236 and references therein) has called attention to descriptions of shamans consuming hallucinatory plants, such as henbane (Hyoscyamus niger) or aconite (Aconitum sp.), and pointed out that these drugs may have caused a person to feel as if s/he had feathers (the sensation of flying in ecstasy) or fur. We can thus assume that the wearing of a fringed or feather-ornamented dress may have had a connection with this experience.

In his classic work on shaman costumes of Siberia, religious scholar Uno Holmberg (later Harva) documented three types of costumes: bear-, deerand bird-type dresses. These costumes were characterised by the central features of the animals which inspired them, such as their bones and skeletons. On the bird-type costumes (Holmberg I922:6), wings were marked by long strips of leather, and other hanging items were sewn to the underseam of the sleeves. In some costumes, whole bird wings were attached to the shoulders. The tail of the bird was imitated by leather strips fixed to the lower edge of the cloak. Throughout the outfit, small leaf-like pieces of iron were recognised as feathers, while bird toes were marked on the boots, with pearls or leather stripes. Also, the headgear was usually made of bird feathers; the eyes of the bird were marked with pearls, for example, and sometimes a complete owl skin was worn as a headdress (Holmberg I922:I3-I4, 20).

Birds, wings and feathers were important in many cultures in which transformations played a role. The previous examples derive from shamanic groups, but we are not suggesting that all uses of feathers on costumes in prehistoric or historic groups - represent shamanic activities. Here the word 'shaman' is used as a general term for animistic cultures in which ritual specialists such as shamans act as transporters between worlds (see e.g. Siikala I999; Sem \& Solovyeva 2006).

These examples draw attention to the variety of ritual, social, ontological and cosmological roles that feathers may have had in specific contexts. Birds were important in historic traditional cultures in the far north (and 
other areas) not only as prey or material goods, but also as integral parts of the worldview. Feathers may have been a medium in interspecies communication, metamorphosis and transformation, and used in paraphernalia and ceremonies in various roles associated with social and personal affinities, identity and kinship. However, direct evidence for the use of feathers in prehistory is scarce because bird feathers belong to organic soft materials - like skin tissue, sinews and hair - which decompose easily in archaeological depositions (see however McGovern-Wilson 2005; Mannermaa 2008a; Serjeantson 2009; Russel 20I8). As the following examples show, wing bones are the main indirect indication for the incorporation of feathers into ancient contexts.

\section{Bird wings in archaeological contexts}

\section{CRANE WINGS IN A CHILD BURIAL AT TAMULA, ESTONIA}

Tamula is a Mesolithic and Neolithic settlement and burial complex in southeast Estonia (Figure 7). Grave VII, that of a child of 6-Io years of age, contained evidence of wing bones from the common crane laid on each hand. The deceased had been laid out in an extended supine position, with hands at the sides. In addition to wing bones, several stone and bone artefacts were found in the grave. The bone artefacts included tooth pendants (Eurasian elk Alces alces, wild boar Sus scrofa, brown bear Ursus arctos) and various figurines depicting birds (Jaanits 1954). The grave was excavated in 1946 by Lembit Jaanits. Radiocarbon dates taken from the Tamula complex suggest a long period of activity, lasting from circa 3900 to 2600 cal BC (Tõrv 2016:174, I84). A sample from the human mandible from grave VII had a radiocarbon age of $5760 \pm 45 \mathrm{BP}$ (Kriiska et al. 2007). After calibration, and when taking into account the fact that a nearby freshwater reservoir may have affected the age of the remains, burial VII in Tamula can be dated to roughly 3700 cal BC (Tõrv 2016:I85-I86).

The presence of crane wing bones suggests that the feathers were still attached to the bones at the time of burial. It is possible that the wings had a role in the burial rite or were associated with the personality or life of the deceased. Whatever interpretation we choose, it seems evident that the special location of wings or wing bones on the hands of the deceased was important, and it suggests that homology was recognised between human hands and crane wings.

\section{JAY WINGS IN A MALE BURIAL AT ZVEJNIEKI, LATVIA}

Our second example of the use of wings derives from Zvejnieki, a famous Middle Mesolithic-Late Neolithic (circa 8300-I800 cal BC) archaeologi- 


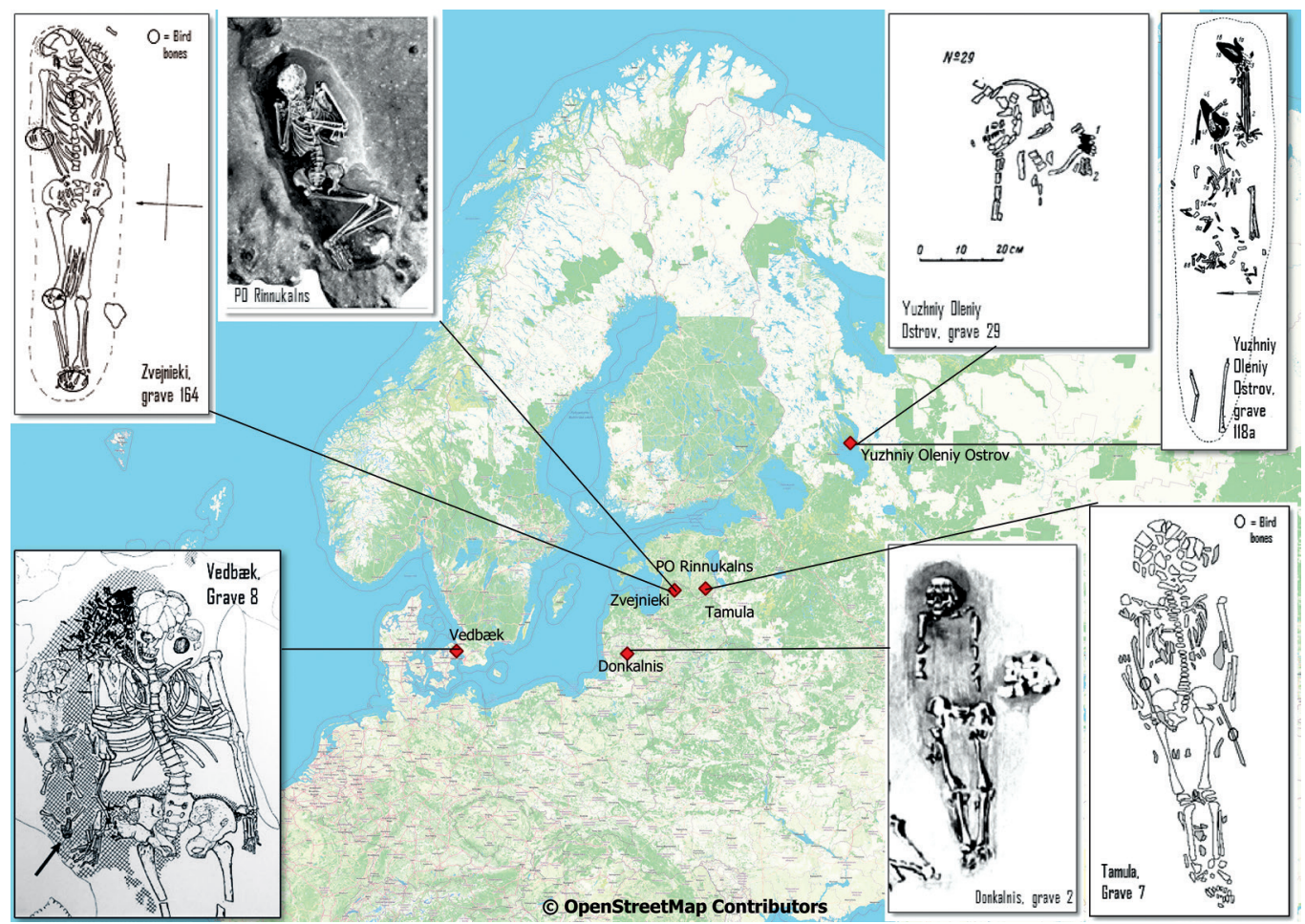

Figure 7. Map of the sites mentioned in the text (Chumysh-Perekat in Altai, Siberia and Çatalhöyük in Turkey not shown). The original illustration of the Rinnnukalns grave was kindly provided by Valdis Berzins. The present figure was produced from the original illustration using an unsupervised image classification method (Roiha 2018). Drawings of YOO graves adapted from Gurina (1956), drawing of the Tamula grave from Kriiska et al. (2007), the Vedbæk grave from Albrethsen \& Brinch-Petersen 1976), and the Donkalnis grave from Butrimas (20I6). Drawing by Johanna Roiha.

cal complex in northern Latvia (Figure 7). A total of 3I7 burials and two nearby settlement phases, Mesolithic and Neolithic, have been uncovered on Zvejnieki Island by Francis Zagorskis in 1964-I97I (Zagorskis 2004; Zagorska 2006). In grave 164,38 carpometacarpus bones (tip of the wings) and three wing phalanges from Eurasian jays (Garrulus glandarius) were found together with various parts of the body of a young adult man (Mannermaa 2008a) (Figure 7). They derived from at least I 7 individual jay birds (Mannermaa 2006, 2008a). Jay bones were found on the chest of the deceased, between the left arm and vertebral column, by the right elbow, by the right knee and near the feet. Also, the deceased wore headgear decorated with tooth pendants (Zagorska \& Lõugas 2000:233). Bone spearheads were found between his legs and on the left side of his chest (Zagorskis 2004).

As proposed earlier (Mannermaa 2006, 2008a), we argue that the jay bones at burial I 64 represent blue wings that were attached to a costume or 
its accessories. Jay bones were found in the soil slightly above the skeleton, which might indicate that the costume with feathers was made of rather thick material, perhaps fur or skin. The location of jay bones on various parts of the skeleton indicates that the costume perhaps had sleeves and extended from the shoulders to the feet (Mannermaa et al. 2007). The reason for using jay wings may have been because of the deep blue colour of the feathers. We can imagine that a costume or garment with several blue wings would have been impressive. The reason for using blue wings may be associated with the jay itself, while the blue colour may also have had special importance.

\section{SWAN WING IN BABY AND WOMAN BURIAL AT VEDBAEK, DENMARK}

Our next example of evidence of wing use derives from the Late Mesolithic Vedbæk complex in Denmark. Seventeen excavated graves at Vedbæk Henriksholm-Bøgebakken, dating to circa 5500-4700 cal BC, contain rich burial goods consisting of animal-derived materials and stone (Albrethsen \& Brinch Petersen 1976; Brinch Petersen et al. 20I5:IIO-III). The double

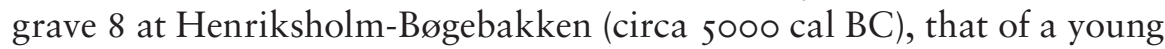
adult female and a newborn child, is iconic (Brinch Petersen et al. 20I5:III). Fragments of the proximal part of the carpometacarpus of a whooper swan (Cygnus cygnus) were found under the baby skeleton. This find was originally interpreted as a 'wing cradle' (Albrethsen \& Brinch Petersen 1976), but the wing could also have been attached to an item of clothing. Overton and Hamilakis (2013) have recently re-interpreted this find and suggested that the swan wing tip was representative of a certain swan individual and was deposited in the grave to acknowledge the intimate relationship between humans and swans. Another possible explanation is that the wing had been used for its insulating properties, for warmth, to separate the body from the ground.

\section{WINGS IN A CHILD BURIAL AT CHUMYSH-PEREKAT, ALTAI, WESTERN SIBERIA}

Fascinating evidence of the use of wing parts on an ancient garment has been recorded at Neolithic burial I 3 at the Chumysh-Perekat cemetery in Altai, western Siberia. Two fragmented wing bones (carpometacarpus) were found in the pelvic area, together with 33 wolf or dog tooth pendants, placed in horizontal order (Fribus \& Grushin 20I7). The bird species has not yet been identified, but based on the in-situ length of the bones (IOcm) they belonged to a large bird. The authors posit that the two bird wings (or parts of wings) with feathers were hanging from a belt ornamented with wolf or dog tooth pendants. The deceased was approximately I0.5-II.5 years old, 
while the sex cannot be determined. The deceased was lying on her/his back, with the head facing towards the northeast. Other finds in the grave include a flint knife and a flint flake, an unspecified bone artefact, a beaver (Castor fiber) bone tool, a stone pendant and a small fish figurine made of mother of pearl. Also, wooden fragments, most likely from the grave structures, were found in a vertical position inside the grave. The authors suggest that the use of bird wings in special hip garments may indicate some special status of the deceased (Fribus \& Grushin 2017).

\section{CRANE WINGS AT A SETTLEMENT SITE AT NEOLITHIC ÇATALHÖYÜK, TURKEY}

Our last example of evidence of wing uses derives from Neolithic Çatalhöyük (Turkey). The high proportion of wing bones discovered at burial sites has provided strong evidence that the feathered wings of several bird species were used for various purposes (Russell 2018). The common crane (Grus grus) was seemingly a special bird in the southern Anatolia region, and scholars have proposed that modified crane wings (distal humerus through phalanges) were used on dance costumes. Nerissa Russell and Kevin J. McGowan (2003) have suggested that humans imitated the dance of the common crane as a means of literally inhabiting its world. Through imitation, humans dancing in costumes can become cranes. Important support for the use of crane wings as guise can be found in the way cranes are depicted at Çatalhöyük and other near Eastern Neolithic sites, always shown in dancing postures. It seems that people in such areas felt a closeness with cranes, perhaps even a kinship (Russel \& McGowan 2003).

\section{Searching for bird feathers in soil samples from mortuary contexts}

\section{ANATOMY AND THE ARCHAEOLOGICAL RETRIEVAL OF FEATHERS}

Bird feathers are organic soft material remains from animals that decompose easily in archaeological contexts. However, compared to hair, for example, feathers are mostly made up of beta-keratins, which differ from the alfa-keratins essential for the formation of mammalian nails and hair, making them tend to preserve better (Chen et al. 20I2; Monnier et al. 20I8). Material evidence from feathers and down, often minuscule traces of barbules, has previously been identified during residue analysis of the surfaces of lithic artefacts, for example (Loy 1993; Hardy et al. 200I, 2008; Hardy 2004; Hardy \& Moncel 20I I; see also Croft et al. 20I6), and in the dental calculus of human remains (Cristiani et al. 20I6; Juhola et al. 20I9). Our 
ongoing study, by contrast, attempts to recover traces of feather remains in soil samples taken from mortuary contexts.

\section{SITES AND SOIL SAMPLES}

We selected three major Mesolithic or other early hunter-gatherer cemeteries in north-eastern Europe to test microarchaeological sampling methods when searching for bird feather remains. The studied burial sites were Yuzhiy Oleniy Ostrov (YOO), by Lake Onega in northwest Russia, Donkalnis in west Lithuania, and Riņnukalns in north Latvia (Figure 7). The soil samples from the sites were approximately $0.5-5$ litres in size, of which only small subsamples were analysed. In the following paragraphs, we discuss the sites in detail (see also Table I).

YOO is the largest known Late Mesolithic burial site in north-east Europe (Figure 7). Altogether, I77 burial remains were recovered during archaeological excavations done in I936-I938 (Gurina I956; Ravdonikas I956; Yakimov I960; Jacobs I992). Most of the graves contained rich burial goods, mainly various artefacts made of materials derived from animals, as well as slate and flint (Gurina 1956). Archaeologists have suggested a I00-200 year timeframe, circa 600-6250 cal BC, as the period when the site was used as a cemetery (O'Shea \& Zvelebil ı984; Schulting et al. forthcoming). Fortunately, soil samples were taken during the excavations, although they often lack precise context information. The samples belong to the archives of the archaeology section of Peter the Great Museum of Anthropology and Ethnography (Kunstkamera) in St Petersburg.

For the purposes of microscopic examination, we selected a red ochre soil sample from grave 29, where five Eurasian elk incisor pendants and two bird bones (species not identified) were found in the area of the left shoulder, possibly indicating the presence of a specific ritual costume (Gurina I956:282). As the grave was badly damaged at the time of the excavation (Figure 7), only a crushed skull, fragments of the jaw, the clavicle and right hand bones were found. The remains belong to an adult individual, but the sex cannot be determined (Yakimov I960). What can be reconstructed, though, is that the deceased had been laid on his/her back, with the head turned to the right, and the entire burial context is covered in a thick layer of red ochre (Gurina I956:282).

We also studied a soil sample from grave I $8 \mathrm{a}$ at YOO. The skeleton was not in anatomical order and several bones are missing. The grave has several bone and antler arrow heads, perforated slate artefacts, and animal tooth pendants. The deceased is an adult man. As with the sample from grave 29 , the exact place of the soil sample from grave i $8 \mathrm{a}$ is not known.

The Donkalnis burial site is located on an island in Lake Biržulis in western Lithuania. It is famous for its eight intact and six partly destroyed in- 
ternments (Figure 7). The burials took place in approximately 3000-6300 cal BC, and settlements from roughly the same periods have been found nearby (Butrimas 20I6, 20I7). We selected grave 2, that of a 20-25 yearold man (circa $6300 \mathrm{cal}$ BC; Butrimas 2016:215), for further study because of the unique arrangement of animal tooth pendants (Eurasian elk and wild boar) around the head and covering the face. This arrangement, covered by a thick layer of red ochre, has been interpreted as a hat or a mask (Butrimas 20I6, 20I7; Mannermaa et al. 2019). The interred individual was buried on his back, in a slightly sitting position. Animal tooth pendants were also found by the hands, knees and feet (Butrimas 2016:208). During the excavations (I98I-I982), approximately five litres of heavily coloured sand were removed from the red ochre concentrations in burial 2, that is, the chest and head area of the deceased. The precise location is not known. Only a small amount of the sand sample has been analysed so far, and it constitutes the material used for the present study.

Rinnukalns in north Latvia is a large freshwater shell midden and burial complex along the bank of the river Salaca, near Lake Burtnieks (Brinker et al. 2020). The first excavations took place in the early nineteenth and early twentieth centuries (Bērziņš et al. 20I4). The most recent excavation, which began in 20I0, revealed intact midden areas and yielded assemblages of well-preserved bones (fish, bird, mammal and human) and mollusc shells, as well as a number of artefacts and hunter-gatherer-type ceramics. For example, several bird figurines were identified from among the material remains at Rinnnukalns, but their precise contexts are not well known (Tõrv et al. 20I7). The midden dates back to roughly $3350 \mathrm{cal} \mathrm{BC}$ (Bērzinšs et al. 20I4:726). Traces of several graves were recovered from the shell midden, some of which date back to the Stone Age (Bērziņš et al. 20I 4; Meadows et al. 20I8).

The material for the present study derives from an undisturbed, newly recovered Stone Age grave, 20I7/I, excavated in 2017 and 2018 (Brinker et

Table I. A list of soil samples studied in this article.

\begin{tabular}{|l|l|l|l|}
\hline Site & Burial & Dating & Location \\
\hline YOO & 29 & $6200-6100$ cal BC & Unknown \\
\hline YOO & $118 a$ & $6200-6100$ cal BC & Unknown \\
\hline Donkalnis & 2 & 6300 cal BC (Butrimas 2016) & $\begin{array}{l}\text { Head and chest area, or separate } \\
\text { stone pile on the left side of the } \\
\text { skeleton. }\end{array}$ \\
\hline Rin,nukalns & $2017 / 1$ & $\begin{array}{l}\text { c. 3350-3100 cal BC } \\
\text { (Brinker et al. 2020) }\end{array}$ & Head and chest area 619 \\
\hline Rin,nukalns & $2017 / 1$ & $\begin{array}{l}\text { c. 3350-3100 cal BC } \\
\text { (Brinker et al. 2020) }\end{array}$ & Under the head 781 \\
\hline
\end{tabular}


al. 2020). The deceased, an adult man, was buried on his back, with arms bent over the chest and legs in a crouched position. The head was facing in the opposite direction of the legs. The head region of the deceased was full of fish bones, interpreted as a food offering for the deceased (Brinker et al. 2020). The grave has been dated to circa $3500-3000 \mathrm{cal}$ BC (Brinker et al. 2020). Fourteen soil samples with excellent context information have been retrieved for further analysis from this newly excavated burial site. So far, we have studied two samples from the Riņnukalns burial site 20I7/I (Table I).

\section{METHODS}

The analysed subsample sizes were quite small during this preliminary testing phase. One to two spoonfuls ( $15-30 \mathrm{ml}$ ) of soil from each sample were separated in a laboratory, and the material was floated in a small amount of water to extract small organic materials from the sand. With the YOO and Donkalnis samples, the red ochre particles coloured the water and needed to be washed away with water by sieving the material through o.Imm filters.

The floated water and sieved particles were pipetted onto glass slides and examined using a Leica DM 2000 LED microscope at Ioox and $400 x$ magnifications. The slides containing fibres were sealed with cover slides using nail polish, and the fibres were documented by photographing them.

The identification and description of the feathers were based on prior work by Brom (I991:29-64) and Dove et al. (2010). The process of identifying the feathers by order or even species was based on a study of the morphological features of the plumulaceous (downy) feathers, while differences were not found in other types of feathers at a microscopic level.

\section{Results}

We identified three feather fragments from the Rinnnukalns grave from the deceased's head and chest area, one feather fragment from the Donkalnis grave 2 from the deceased's head and chest area, and one fragment from YOO grave 29 (Table 2). We did not find feather remains from the sample taken from grave I $8 \mathrm{a}$ at YOO, nor the sample taken from under the head of the deceased at the Rinnukalns grave site. The find material consists mostly of barbules, which are the smallest division points of the feather, branching out from the rachilla of the barbs (see Dove \& Koch 20I0:20). A barbule can be divided into a base part (see the find from YOO) and a narrow pennulum (see, for instance, the find from Riņnukalns). A barb 
Table 2. Feather remains from hunter-gatherer burials. Photos: Tuija Kirkinen.

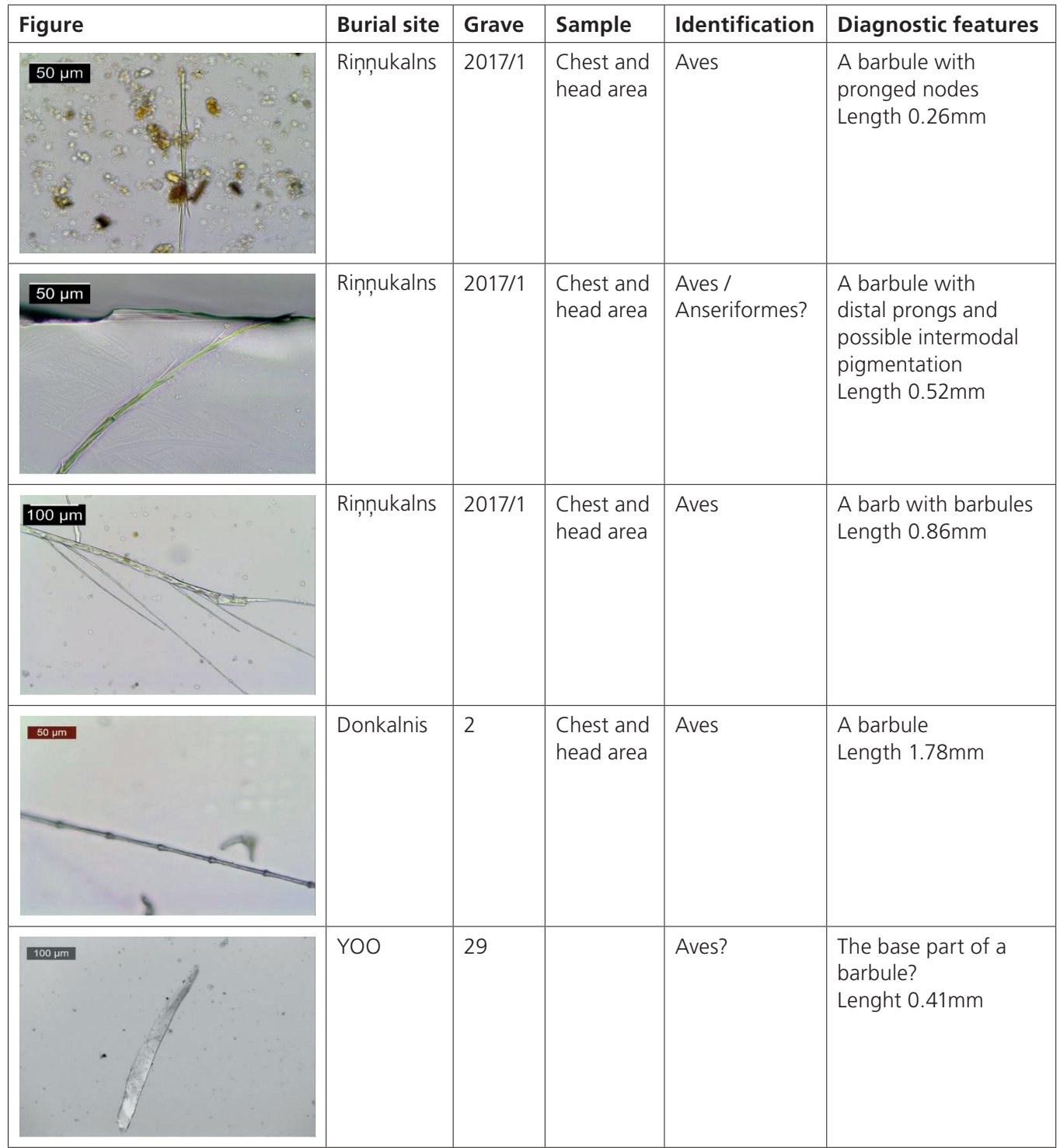

rachilla with some barbules was also found at the Rinnukalns grave site (Figure 8).

None of the feather finds can be identified by species based on their morphology. The fragments were $0.26-\mathrm{I} .78$ millimetres in length, with barely any species diagnostic features. As an exception, the barbule from Rinnnukalns had distal prongs, which may indicate that the feather is from a waterfowl (Anseriformes). 


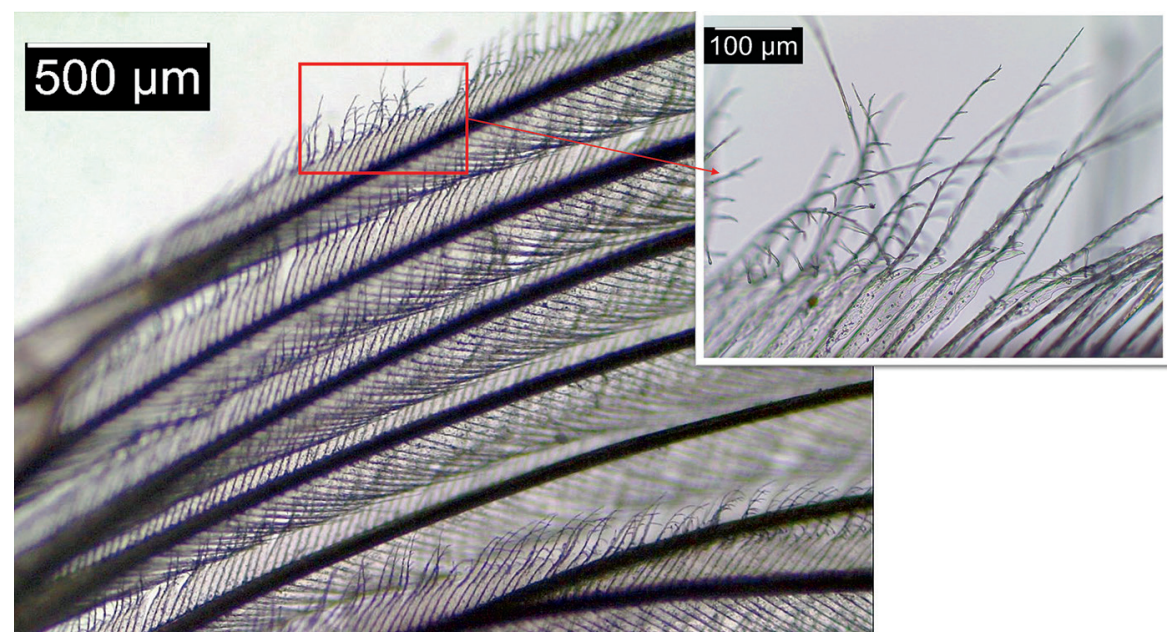

Figure 8. Light microscopic image of pennaceous feather barbs with barbules (close-up view on the right). Photo: Tuija Kirkinen.

\section{Discussion}

\section{UNIQUE EVIDENCE OF FEATHERS FROM HUNTER-GATHERER BURIALS}

Our study provides the first direct evidence of the use of feathers in huntergatherer burial practices in north-eastern Europe. It has long been suspected that feathers were used in burial practices, but we demonstrate that their fragments can still be recovered from the soil in the graves. Three of our five samples were shown to contain recognisable (although not identifiable) feather fragments.

All three samples originated from soil closely associated with the skeletal remains in the grave, but only at Rinnukalns was exact documentation created during the sampling. Here, the feathers could derive from headgear, but other uses are also possible as well; feathers (or wings) may have been attached to the collar or a necklace, or they may derive from a pillow.

Grave 2 at Donkalnis is exceptional due to the mask or headgear covering the eyes, ears and nostrils of the deceased, and it would be logical to think that feathers were part of this ceremonial mask or headgear. However, we can only speculate, as the precise location of the soil sample is not known. No other bird finds were reported from this burial site before our analysis, which makes the feather find even more important. Burial II 5 of an adult man at YOO bears some resemblance to grave 2 at Donkalnis, as it contains evidence of a mask or headgear ornamented with animal tooth pendants (Gurina 1956). Unfortunately, we lack a soil sample from grave II5. The feathers found in the soil at these grave sites do not on their own 
indicate that the persons were shamans or leaders. However, when taken together with other finds, the feather fragments found in Donkalnis grave 2 support the idea that the person wore headgear ornamented with feathers, a mask clearly resembling some of the examples from garments worn more recently by shamans. Our contextual knowledge of the soil samples from Donkalnis and YOO is scarce, and we cannot do more than hypothesise at this point that the feathers may have belonged to headgear or a mask. We anticipate that in the future, we will obtain much more new evidence of feathers found in graves at YOO, Donkalnis and Riņnukalns; microscopic analysis of these red ochre samples has just started.

\section{HUMAN-WING AND HUMAN-FEATHER RELATIONS IN THE MESOLITHIC OF NORTHERN EUROPE}

The manifold evidence for the use of feathers in traditional societies speaks to their importance already during the prehistoric era. This is in contrast with the scarce zooarchaeological evidence hitherto found among Stone Age hunter-gatherers. Our results support the hypothesis that this lack is related to taphonomic problems. First, we pointed out that the presence of bird wing bones in archaeological contexts usually indicates a complete wing with feathers (see also Serjeantson 2009; Fribus \& Grushin 20I7; Russell 20I8).

Second, we have shown that microscopic bird feather parts can indeed be observed in hunter-gatherer burials. This serves as evidence of the use of feathers or wings in funeral rituals, even in contexts where no bones are associated. We cannot identify, though, exactly how feathers were used in the burial practices in such contexts. The next step in our study is to systematically analyse the collected samples from complete burials in order to find contextually well-documented feather fragments. The systematic collection process means that soil samples from all areas of the burial context will be taken and documented.

Samples from better documented contexts will provide us with an opportunity to find stronger evidence that feathers were used in clothes and garments at prehistoric burial sites and in other contexts. This would significantly improve our understanding of why feathers, wings and bird species were important for Mesolithic and other prehistoric communities. Our microarchaeological studies will undoubtedly complement the fascinating osteological work already being undertaken on this subject.

\section{Conclusions}

We have discussed the uses of feathers and wings in early prehistoric archaeological records and presented some preliminary results from our re- 
search, based on microarchaeological analyses of soil samples from prehistoric hunter-gatherer funerary contexts. Our results show that feathers and animal hair can survive even in samples excavated decades ago. They also underline that the most useful way to gather data from burial contexts is to engage in systematic sampling and documentation practices during excavation and separately investigate various parts of the mortuary feature. Our ongoing microscopic studies will shed new light on the uses of feathers by prehistoric communities in everyday life as well as in rituals and ceremonies, giving further possibilities to understand past mortuary practices and human-animal relations.

We have just begun to learn what kind of information microanalyses of the soil can provide for mortuary archaeology, for instance, by revealing elements that are otherwise almost invisible in archaeological studies. Our future aim is to obtain more evidence of feather fragments in burial contexts in order to investigate and interpret their various roles, meanings and functions.

\section{Acknowledgements}

We thank Adomas Butrimas for providing a sample from Donkalnis, Dmitriy Gerasimov for providing samples from YOO, and the research project 'Rinnukalns', headed by the German Research Foundation (DFG-project number 335674082), for providing samples from Rinnukalns. We thank the Russian Museum of Ethnography for permission to publish photographs in Figures 2, 4, 5 and 6, Peter the Great Museum of Anthropology and Ethnography (Kunstkamera) for permission to publish the photograph in Figure I, and the Finnish Heritage Agency for permission to publish the photograph in Figure 3. We are thankful to Johanna Roiha for preparing the Figure 7. The project was funded with a grant from the Kone Foundation (for KM) and the Academy of Finland (for TK). This study is part of a project that has received funding from the European Research Council (ERC), the European Union's Horizon 2020 research and innovation programme, under grant agreement No 864358 .

\section{References}

Ahola, M., Kirkinen, T., Vajanto, K. \& Ruokolainen, J. 2018. On the Scent of an Animal Skin: New Evidence on Corded Ware Mortuary Practices in Northern Europe. Antiquity. Vol. 92 pp. II8-I3I.

Aguilera, C. 20I0. The Transformations of the Quetzal Bird. In: Campana, D., Crabtree, P., deFrance, S.D., Lev-Tov, J. \& Choyke, A.M. (eds). Anthropological Approaches to 
Zooarchaeology: Colonialism, Complexity and Animal Transformations, pp. 237-243. Oxford: Oxbow Books.

Albrethsen, S.E. \& Brinch Petersen, E. I976. Excavation of a Mesolithic Cemetery at Vedbæk, Denmark. Acta archaeologica. Vol. 47 pp. I-28.

Back Danielsson, I.-M. 2007. Masking Moments: The Transitions of Bodies and Beings in Late Iron Age Scandinavia. Stockholm: University of Stockholm.

Beatty, M.T. \& Bonnichsen, R. I994. Dispersing Aggregated Soils and other fine Earth in the Feld for the Recovery of Organic Archeological Materials. Current Research in the Pleistocene. Vol. II pp. 73-77.

Bērziņš, V., Brinker, U. [...] Stümpel, H. \& Zagorska, I. 20I 4. New Research at Rinnukalns, a Neolithic Freshwater Shell Midden in Northern Latvia. Antiquity. Vol. 88 pp. 7 I5-732.

Brinch Petersen, E. \& Meiklejohn, C. 2003. Three Cremations and a Funeral: Aspects of Burial Practice in Mesolithic Vedbaek. In: Kindgren, H., Knutsson, K., Larsson, L. \& Loeffler, D. (eds). Mesolithic on the Move: Papers Presented at the Sixth International Conference on the Mesolithic in Europe, Stockholm 2000, pp. 485-493. Oxford: Oxbow books.

Brinch Petersen, E., Jønsson, J., Juel, C. \& Kjaer, A. 20I5. Diversity of Mesolithic Vedbæk. Acta archaeologica. Vol. 86(I) pp. 7-I3.

Brinker, U., Valdis Bērziņš, V. [...] Zagorska, I., \& Schmölcke, U. 2020. Two Burials in a unique Freshwater Shell Midden: Insights into Transformations of Stone Age Hunterfisher daily Life in Latvia. Archaeological and Anthropological Sciences. Vol. I2(5) article 97.

Brom, T.G, I99I. The Diagnostic and Phylogenetic Significance of Feather Structures. Amsterdam: Academisch Proefschrift.

Butrimas, A. 20I6. Biržulis Lake Islands Donkalnis and Spiginas Mesolithic Cemeteries (West Lithuania). In: Grünberg, J., Gramsch, B., Larsson, L., Orschiedt, J. \& Meller, H. (eds). Mesolithic Burials: Rites, Symbols and Social Organisation of early Postglacial Communities. Mesolithische Bestattungen: Riten, Symbole und soziale Organisation früher postglazialer Gemeinschaften (Intern. Conference Halle/Sa., I8.-21.9.20I3), pp. I95-2I7. Halle (Saale): Landesmuseum fur Vorgeschichte.

Butrimas, A. 20I7. From Mesolithic to Early Christianity: The Development of the Ritual Complex in the Northern Part of Lake Biržulis (Lithuania) According to Archaeological, Linguistic and Historical Research. Sociology and Anthropology. Vol. 5 pp. 204-2I9.

Chen Siang Ng., Ping Wu. [...] Wen-Hsiung Li \& Cheng-Ming Chuong 20I 2. The Chicken Frizzle Feather is Due to an a-Keratin (KRT75) Mutation That Causes a Defective Rachis. PLoS Genet. Vol. 8(7) article eroo2748.

Croft, S., Monnier, G., Radini, A., Little, A. \& Milner, N. 20I6. Lithic Residue Survival and Characterisation at Star Carr: A Burial Experiment. Internet Archaeology. Vol. 42 https://doi.org/IO.III4I/ia.42.5.

Cristiani, E., Radini, A., Edinborough, M. \& Borić, D. 20ı6. Dental calculus reveals Mesolithic Foragers in the Balkans Consumed Domesticated Plant Foods. PNAS. Vol. II 3 pp. $10298-10303$.

Dove, C.J. \& Sandra, L. \& Koch, S.L. 20Io. Microscopy of Feathers: A Practical Guide for Forensic Feather Identification. JASTEE. Vol. I(I) pp. I5-6I.

Furst, P.T. 1991. Crowns of Power: Bird and Feather Symbolism in Amazonian Shamanism. In: Reina, R.E. \& Kensington, K.M. (eds). The Gift of Birds: Feather and Featherworks of native South American Peoples, pp. 92-109. Philadelphia, PA: University of Pennsylvania, University Museum. 
Fribus, A.V. \& Grushin, S.P. 20I7. Bird Feathers in the Makeup of a Neolithic Costume (based on the Materials of the Chumysh-Perekat Cemetery in the south of West Siberia) = А. В. Фрибус, С. П. Грушин. Перья птиц в системе оформления неолитического костюма (по материалам могильника Чумыш-Перекат на юге Западной Сибири). Записки Института истории материальной культуры РАН. СПб.: ИИМК РАН, 2017. № 16.200 с., pp. 20-34.

Gilligan, I. 20I9. Climate, Clothing, and Agriculture in Prehistory. Linking Evidence, Causes, and Effects. Cambridge: Cambridge University Press.

Gurina, N. 1956 = Гурина Н.Н. I956. Оленеостровский могильник // Материалы и исследования по археологии СССР, № 47, М-Л.

Hardy, B. L. 2004. Neanderthal behaviour and Stone Tool Function at the Middle Palaeolithic Site of La Quina, France. Antiquity. Vol. 78 pp. 547-565.

Hardy, B.L., Bolus, M. \& Conard, N.J. 2008. Hammer or Crescent Wrench? Stone-tool form and Function in the Aurignacian of southwest Germany. Journal of Human Evolution. Vol. 54 pp. 648-662.

Hardy, B.L., Kay, M., Marks, A.E. \& Monigal, K. 200I. Stone Tool function at the Paleolithic Sites of Starosele and Buran Kaya III, Crimea: Behavioral Implications. Proceedings of the National Academy of Sciences of the United States of America. Vol. 98 pp. I0972-10977.

Hardy, B.L. \& Moncel, M. 20I r. Neanderthal use of Fish, Mammals, Birds, Starchy Plants and Wood I25-250,000 Years Ago. PloS One. Vol. 6 article e23768.

Holmberg, U. 1922. The Shaman Costume and its Significance. Annales Universitatis fennica Aboensis. Ser. B Vol. I/2, pp. 3-36.

Hurcombe, L. 20I4. Perishable Material Culture in Prehistory: Investigating the Missing Majority. London \& New York: Routledge.

Jaanits, L. I954. Novye dannye po neolitu Pribaltiki. Sovetskaya Arkheologiya. Vol. I9 pp. I59-204.

Jacobs, K. I992. Human Population differentiation in the peri-Baltic Mesolithic: the Odontometrics of Oleneostrovskii mogilnik (Karelia). Human Evolution. Vol. 7(4) pp. 33-48.

Juhola, T., Henry, A., Kirkinen, T., Laakkonen, J. \& Väliranta, M. 20I9. Phytoliths, Parasites, Fibers and Feathers from Dental Calculus and Soil from Iron Age Luistari Cemetery, Finland. Quaternary Science Reviews. Vol. 222 article 105888.

Kelly, L. 20ıо. A Bird's Eye View of Ritual at the Cahokia Site. In: Campana, D., Crabtree, P., deFrance, S.D., Lev-Tov, J. \& Choyke, A.M. (eds). Anthropological Approaches to Zooarchaeology. Colonialism, Complexity and Animal Transformations, pp. I-II. Oxford: Oxbow Books.

Kirkinen, T. 2019. Between skins - Animal Skins in the Iron Age and Historical Burials in eastern Fennoscandia. PhD thesis, University of Helsinki. Helsinki: Unigrafia. https://helda.helsinki.fi/bitstream/handle/IOI38/299558/BETWEENS. pdf? sequence $=\mathrm{I} \&$ isAllowed $=\mathrm{y}$

Kirkinen, T., Riikonen, J., Dove, C. \& Ruohonen, J. in press. The Identification and Use of Fur and Feathers Excavated from the Late Iron Age and Early Medieval (I2th-I3th centuries) Ravattula Ristimäki Cemetery in Kaarina, Southwest Finland. Fennoscandia archaeologica.

Kriiska, A., Lõugas, L., Lõhmus, M., Mannermaa, K. \& Johanson, K. 2007. New AMS dates from Estonian Stone Age Burial Sites. Estonian Journal of Archaeology. Vol. I I pp. 83-I2I. 
Lehtinen, I. 2002a. Siperian kansat kulttuurien museossa. In: Lehtinen, I. (ed.), Siperia. Taigan ja tundran kansoja, pp. 23-46. Jyväskylä: Gummerus.

Lehtinen, I. 2002b. Siperian kansojen puvut -käytännöllisyyttä ja ylellisyyttä. In: Lehtinen, I. (ed). Siperia. Taigan ja tundran kansoja, pp. I08-I45. Jyväskylä: Gummerus.

Loy, T.H. I993. The artifact as site: An example of the Biomolecular analysis of Organic Residues on Prehistoric Tools. World Archaeology. Vol. 25, pp. 44-63.

McGovern-Wilson, R. 2005. Feathers flying in Paradise: the taking of Birds for their Feathers in Prehistoric Polynesia. In: Grupe, G. \& Peters, J. (eds). Feathers, Grit and Symbolism. Birds and Humans in the Ancient Old and New Worlds. Documenta Archaeobiologiae. Vol. 3 pp. 20I-22I.

Mannering, U. 20I7. Iconic Costumes. Scandinavian Late Iron Age Costume Iconography. Ancient Textiles series 25. Oxford \& Philadelphia: Oxbow Books.

Mannermaa, K. 2006. Bird Remains in the Human Burials at Zvejnieki, Latvia. Introduction to Bird Fnds and a Proposal for Interpretation. In: Larsson, L. \& Zagorska I. (eds). Back to the Origin. New Research in the Mesolithic-Neolithic Zveinieki Cemetery and Environment, northern Latvia. Acta Archaeologica Lundensia Series. Vol. 8(52), pp. 289-300. Stockholm: Almqvist \& Wiksell.

Mannermaa, K., Zagorska, I., Jungner, H. \& Zarina, G. 2007. New Radiocarbon dates of Human and Bird Bones from Zvejnieki Stone Age Burial Ground in northern Latvia. Before Farming. Vol. I pp. I-I 2.

Mannermaa, K. 2008a. Birds and Burials at Ajvide (Gotland, Sweden) and Zvejnieki (Latvia) about 8000-3900 BP. Journal of Anthropological Archaeology. Vol. 27 pp. $20 \mathrm{I}-225$.

Mannermaa, K. 2008b. The Archaeology of Wings. Birds and People in the Baltic Sea Region during the Stone Age. Helsinki: Gummerus.

Mannermaa, K. 20I8. Humans and Raptors in northern Europe and northwestern Russia before Falconry. In: Gersmann, K.-H. \& Grimm, O. (eds). Raptor and Human - Falconry and Bird Symbolism throughout the Millennia on a Global Scale, pp. 257-276. Kiel/Hamburg: Wachholtz Verlag -- Murmann Publishers.

Mannermaa, K., Kirkinen, T. \& Juhola, T. 20I9. Nauji plunksnų naudojimo vélyvojo mezolito ritualiniame kontekste įrodymai. Donkalnio 2 kapo (Lietuva) mikroarcheologija (apie 6000 m. pr. Kr. (BC) / New evidence of feather use in Late Mesolithic Ritual Context. Microarcheology of the Donkalnis Grave 2, Lithuania (c. 6000 cal BC). In: Butrimas, A. (ed). Biržulis. Medžiotojai, žvejai ir senieji žemdirbiai X-II tūkstantmetyje pr. Kr. I. Paminklu tyrinejiimai / Biržulis. Hunters, Fishermen and Ancient Farmers I0 000-I000 BC. I. Research of the Monuments, pp. 374-38I. Vilnius.

Meadows, J., Bērziņš, V., [...] Zagorska, I. \& Zariṇa, G. 20I8. Stone-Age Subsistence Strategies at Lake Burtnieks, Latvia. Journal of Archaeological Science: Reports. Vol. I7 pp. 992-I006.

Metcalfe, J. 20I8. Pleistocene Hairs: Microscopic Examination Prior to Destructive Analysis. PaleoAmerica. Vol. 4, pp. I6-30.

Monnier, G., Frahm, E., Luo, B. \& Missal, K. 20I8. Developing FTIR Microspectroscopy for the Analysis of Animal-Tissue Residues on Stone Tools. Journal of Archaeological Method and Theory. Vol. 25 pp. I-44.

Morell, V. 1994. Pulling Hair from the Ground. Science. Vol. 265 p. 74I.

Napolskikh, V. I992. Proto-Uralic World Picture: a Reconstruction. In: Hoppal, M \& Pentikäinen, J. (eds). Northern Religions and Shamanism, pp. 3-2o. Budapest: Akadémiai kiadó. 
Nieves Zedeño, M., Field Murray, W. \& Chandler, K. 20I8. The Inalienable-Continuity Continuum in the Circulation of Birds on the North American Plains. In: HarrisonBuck, E. \& Hendon, J.A. (eds). Relational Identities of Other-than-Human Agency in Archaeology, pp. I00-I 25. Louisville: University Press of Colorado.

O’Shea, J. \& Zvelebil. M. I984. Oleneostrovski Mogilnik: Reconstructing Social and Economic Organization of Prehistoric Forager northern Russia. Journal of Anthropological Archaeology. Vol. 3 pp. I-40.

Overton, N.J. \& Hamilakis, Y. 20I3. A Manifesto for a Social Zooarchaeology. Archaeological dialogues. Vol. 20 pp. III-I36.

Prokofyeva. Ye, D. 1963. The Costume of an Enets Shaman. In: Michael, H.N. (ed). Studies in Siberian shamanism, Arctic Institute of North America, anthropology of the North: translations from Russian sources, No. 4. Toronto: University of Toronto Press for the Arctic, Institute of North America.

Rast-Eicher, A. 2016. Fibres. Microscopy of Archaeological Textiles and Furs. Budapest: Archaeolingua.

Ravdonikas I956= Равдоникас В.И. І956. Неолитический могильник на Южном Оленьем острове Онежского озера. Вступительная статья - МИA. Vol. 47 pp. 7-24

Reina, R.E. \& Kensington, K.M. I991. The gift of birds. Feather and featherworks of native South American peoples. University Museum Monograph 75. Philadelphia, PA: University of Pennsylvania.

Roiha, J. 20I8. Arkeologisten kenttätöiden dokumentointi-kuvaluokittelumenetelmien testaus ja pohdintaa tulevaisuuden dokumentointimenetelmistä. MA-thesis, University of Helsinki. http://hdl.handle.net/IOI38/289747.

Russell, N. 20I8. Spirit Birds at Neolithic Çatalhöyük. Environmental Archaeology. The Journal of Human Palaeoecology. Vol. 24(4) pp. 277-387. https://doi.org/IO.IO80/I4 6I 4I03.20I7.I 422685 .

Russell, N. \& McGowan, K.J. 2003. Dance of the Cranes: Crane Symbolism at Çatalhöyük and beyond. Antiquity. Vol. 77, pp. 445-455.

Schulting, R., Higham, T. [...] Gerasimov, D., \& Weber, A. Forthcomming. Complex human response to the $8.2 \mathrm{ka}$ BP event in northern Europe.

Sem, T. \& Solovyeva, K. 2006. White \& Black Shamans. In: Konovalov, A., Sem, T. \& Solovyeva, K. (eds). Between the Worlds: Shamanism of the Peoples of Siberia, pp. 25827I. Moscow: Khudozhnik i Kniga Publishers.

Serjeantson 2009. Birds. Cambridge: Cambridge University Press.

Siikala, A.-L. 1999. Suomalainen samanismi. Helsinki: Suomalaisen Kirjallisuuden Seura.

Siikala, A.-L. 2002. Mythic Images and Shamanism. A Perspective on Kalevala Poetry. Helsinki: Suomalainen tiedeakatemia.

Sillitoe, P. 1988. From Head-Dresses to Head-Messages: The Art of Self-decoration in the high-lands of Papua New Guinea. Man (New Series). Vol. 23 pp. 298-3I8.

Taksami, C.M. 200I. The Shamans's Path to Heaven. In: Pentikäinen, J., Saressalo, H. \& Taksami, C.M. (eds). Shamanhood Symbolic and Epic, pp. I I-I8. Budapest: Akadémiai Kiadó.

Taru, P. \& Backwell, L. 20I3. Identification of Fossil Hairs in Parahyaena brunnea Coprolites from Middle Pleistocene Deposits at Gladysvale cave, South Africa. Journal of Archaeological Science. Vol 40 pp. 3674-3685.

Tõrv, M. 2016. Persistent Practices. A Multi-Disciplinary Study of Hunter-Gatherer Mortuary Remains from c. 6500-2600 cal. BC, Estonia. Dissertationes Archaeologiae Universitatis Tartuensis. 
Tõrv, M., Lübke, H., Meadows, J., Zagorska, I. \& Bērziņš, V. 20I9. Soul carriers to the Afterlife? The Context and meaning of the Bird Figurines from Rinnukukalns In: Valentin Eriksen, B., Abegg-Wigg, A., Bleile, R. \& Ickerodt, U. (eds). Interaktion ohne Grenzen. Beispiele archäologischer Forschungen am Beginn des $2 \mathrm{I}$. Jahrhunderts. Interaction without borders. Exemplary archaeological research at the beginning of the 2 Ist century. Band I(I), pp. 49-62. Kiel: Wachholtz Verlag.

Wilson, A. 2008. The Decomposition of Hair in the Buried Body Environment. In: Tibbett, M. \& Carter, D.O. (eds). Soil Analysis in Forensic Taphonomy. Chemical and Biological Effects of Buried Human Remains, pp. I23-I5I. Florida: Boca Raton.

Zagorska, I. 2006. Radiocarbon Chronology of the Zvejnieki Burials. In: Larsson, L. \& Zagorska, I. (eds). Back to the Origin. New Research in the Mesolithic-Neolithic Zvejnieki Cemetery and Environment, northern Latvia. Acta Archaeologica Lundensia Series. vol. 8 (52), pp. 9I-I I 4. Stockholm: Almqvist \& Wiksell.

Zagorska, I. \& Lõugas, L. 2000. The tooth pendant head-dresses of Zvejnieki cemetery. In: Lang., V. \& Kriiska, A. (eds). De temporibus antiquissimis ad honorem Lembit Jaanits. Muinasaja teadus. Vol. 8 pp. 223-244.

Zagorskis, F. 2004. Zvejnieki (Northern Latvia) Stone Age Cemetery. BAR International series I292. Oxford: Archaeopress.

Yakimov 1960 = Якимов В.П. 1960. Антропологические материалы из неолитического могильника на Южном Оленьем острове (Онежское озеро). Сборник Музея антропологии и этнографии, т.19. Институт этнографии им. Н.Н. Миклухо-Маклая АН СССР; отв. ред. С.П. Толстов. М-Л.: Изд-во АН СССР, І960. 